\title{
Wild grapevine (Vitis vinifera subsp. sylvestris) in the Hyrcanian relict forests of northern Iran: an overview of current taxonomy, ecology and palaeorecords
}

\author{
Alireza Naqinezhad ${ }^{1}$ - Elias Ramezani ${ }^{2}$ - Morteza Djamali ${ }^{3} \cdot$ Annik Schnitzler $^{4}$. \\ Claire Arnold 5
}

\begin{abstract}
Due to severe anthropogenic impacts on lowland and submontane zones of the Hyrcanian forests of northern Iran, wild grapevine (Vitis vinifera subsp. sylvestris), a sporadically distributed woody liana, is currently considered an endangered species. Using data from the literature and 34 studied populations, herbarium assessments and nine palynological sites, we provide an overview of its taxonomy, distribution and ecology in the first part of the investigation. The separation of the two subspecies, namely $V$. sylvestris
\end{abstract}

Project Funding: This research was supported by the Centre for International Scientific Studies and Collaboration (CISSC) and the French Embassy in Tehran under the "Gundishapour" project.

Alireza Naqinezhad

a.naqinezhad@umz.ac.ir

1 Department of Biology, Faculty of Basic Sciences, University of Mazandaran, Babolsar, Mazandaran, Iran

2 Department of Forestry, Faculty of Natural Resources, Urmia University, Urmia, Iran

3 Institut Méditerranéen de Biodiversité et d'Ecologie (IMBE, UMR 7263, CNRS-Aix Marseille Université-IRD-Université d'Avignon), Europôle méditerranéen de 1'Arbois, bâtiment Villemin, BP80, 13545 Aix-En-Provence Cedex 04, France

4 Laboratoire Interdisciplinaire des Environnements Continentaux LIEC - UMR 7360, CNRS, University of Lorraine, Metz, France

5 University of Lausanne, Unicentre, 1015 Lausanne, Switzerland subsp. anebophylla and V. sylvestris subsp. trichophylla (sensu Flora Iranica), based on their leaf indumentums, could not be confirmed by our examination of herbarium materials and field observations. Indumentum of the leaves is a result of leaf polymorphism in different Vitis specimens and can be strongly influenced by environmental conditions. Vitis vinifera subsp. sylvestris grows in a wide range of habitats including wetlands, seasonal stream sides in closed forests, alluvial beds of large rivers, sand dune shrublands and forested wetlands (alder forests). Parrotia persica and Carpinus betulus were the most frequent host species in the studied populations. In the Hyrcanian region, no pollen record of Vitis older than the Mid-or Late-Holocene has yet been established. Despite the intrinsic problem in pollen identification by normal (i.e., light) microscopy of wild from cultivated grapevines, the significant values and persistent occurrence of Vitis pollen since the Mid-Holocene (before the Bronze Age) in the Hyrcanian pollen records may imply the onset of viticulture in low- to mid-elevation sites in the region. This represents an argument to consider the Hyrcanian region as a possible domestication center for $V$. vinifera. However, the question of wild versus cultivated origin of grapevines in the Hyrcanian pollen records and the possible date of its domestication and/or cultivation will remain open until further palynological studies are undertaken.

Keywords Domestication - Grapevine · Hyrcanian forests · Pollen · Vitis

\section{Introduction}

Since several wild and naturally occurring Asian and American Vitis species are now recognized as valuable sources of resistant genes against diseases and 
environmental stresses (Ruel and Walker 2006; Wan et al. 2008; Zecca et al. 2012), scientists have dedicated great attention to the study and development of cultivars of Vitis vinifera $\mathrm{L}$. subsp. vinifera, and to the study of the wild form of the cultivated grapevine, $V$. vinifera subsp. sylvestris (C. C. Gmel.) Hegi (e.g., This et al. 2006). Habitat loss, and the spread of pests and diseases, (particularly Phylloxera), have caused the extinction of most wild populations during the last century (Arrigo and Arnold 2007; de Andres et al. 2012; Schneider et al. 2015).

The genus Vitis L. (Vitaceae family) includes about 70 woody lianas distributed mostly in the temperate regions of the Northern Hemisphere (This et al. 2006; Zecca et al. 2012). They include 34 American and 37 Asian species which are geographically separated (GRIN 2016), as well as the European-Middle Asian wild grapevine ( $V$. vinifera subsp. sylvestris), believed to be the living ancestor of modern grapevine cultivars (This et al. 2006; Terral et al. 2010).

Wild grapevine ( $V$. vinifera subsp. sylvestris) is a tendrillar woody, dioecious liana, indigenous to a wide portion of Eurasia extending from Portugal to Turkmenistan, and from Rhine riversides to the northern forests of Tunisia (This et al. 2006). It has entire, trilobate deciduous leaves, often hairy on the under surface. Female plants produce bunch of grapes, that appear as black berries of $1 \mathrm{~cm}$ in diameter, containing up to four round seeds (Hegi 1966). The diversity centre of the subspecies seems to be located in the Middle East, from the Anatolian Peninsula to the Transcaucasian regions and the Hyrcanian area (Grassi et al. 2008; Zecca et al. 2012), where there exists the oldest living Eurasian Vitis species (Zecca et al. 2012).

The Hyrcanian area in the north of Iran, as well as the plains around the Black Sea, have acted as the main sources for conservation of grapevine germplasm during the Quaternary glaciations (Leroy and Roiron 1996; Leroy and Arpe 2007), and probably the only regions of continuous presence of the genus since the Tertiary period. Regions close to the Caspian and the Black seas also acted as refugia during the Last Glacial Maximum (LGM, 23,000-18,000 years before present) for the wild grapevine as well as for several thermophilous forest species (species growing in higher temperatures), such as Parrotia persica (DC.) C. A. Mey., Gleditsia caspia Desf. Zelkova carpinifolia (Pall.) K. Koch, and Pterocarya fraxinifolia (Poir.) Spach (Van Zeist and Bottema 1977; Grassi et al. 2008; Akhani et al. 2010).

Despite a number of genetic, ecological and taxonomic studies on wild grapevine (e.g., Zecca et al. 2012; Ekhvaia and Akhalkatsi 2010; Rubio et al. 2012; Ekhvaia et al. 2014) and a few genetic studies on wild and cultivated grapevines of western Iran (Ramezani et al. 2009; DoulatyBaneh et al. 2007, 2013, 2014; Karataş et al. 2014), specific studies on habitat characteristics, taxonomical features and palaeoecological evidence of the occurrence of this species in the Hyrcanian area are lacking. This paper deals with taxonomical delimitation, habitats, palaeorecords and current distribution of $V$. vinifera subsp. sylvestris in the relict Hyrcanian area of northern Iran.

\section{Materials and methods}

\section{Study area}

The study area includes the south Caspian lowlands and plains along with the northern slopes of the Alborz Mountains, extending over $800 \mathrm{~km}$ from the forests of the Golestan National Park (longitude $56^{\circ} \mathrm{E}$ ) near the Turkmenistan border to the forests close to the border of Iran and the Azerbaijan Republic (longitude $48^{\circ} \mathrm{E}$ ) (Fig. 1). The region is bioclimatically different from other parts of Iran (Akhani et al. 2010; Djamali et al. 2011b), benefiting from a mild climate that has harboured the relict thermo-mesophilous Hyrcanian forest during the Quaternary glacial climates (Zohary 1973; Frey and Probst 1986).

The study area has an annual average rainfall that ranges from $2045 \mathrm{~mm}$ in the west to $866 \mathrm{~mm}$ in the east (forest area of Golestan National Park), and average minimum temperatures of the coldest month higher than the freezing point $\left(0^{\circ}\right.$ C) (Akhani 2005; Akhani et al. 2010). Considering the spatial analysis of precipitation seasonality, there are different precipitation regimes across the Hyrcanian region (Domoers et al. 1998). According to recent bioclimatic classification of Iran based on Rivas-Martínez system, the Hyrcanian region is mainly affected by temperate oceanic climates followed by Mediterranean pluviseasonal oceanic, Mediterranean xeric oceanic and Mediterranean pluviseasonal continental bioclimates (Djamali et al. 2011b).

The study area is predominantly deciduous closed forests (Hyrcanian forests) restricted to the south Caspian lowlands up to the adjoining northern slopes of the Alborz mountain range, one of the largest mountain ranges in Iran (Frey and Probst 1986). The forests contain relicts of the Arcto-Tertiary and Indo-Malesian floras and are divided altitudinally into lowland and montane zones. Lowland forests include important evergreen broad-leaved species and range up to $1000 \mathrm{~m}$ a.s.l and are characterized by Acer velutinum Boiss., Carpinus betulus L., Pterocarya fraxinifolia, Quercus castaneifolia C. A. Mey., Zelkova carpinifolia, Albizia juilibrissin Durazz., Buxus hyrcana Pojark., Diospyros lotus L., Gleditsia caspia, Ilex spinigera (Loes.) Loes., Parrotia persica, Ruscus hyrcanus Woronow, Hedera pastuchovii Woronow, Smilax excelsa L., V. vinifera subsp. sylvestris and Dioscorea communis (L.) Cassick and Wilkin. Montane forests are located mainly from 1000 up to 2000 m.a.s.l. and are characterized by Fagus orientalis 


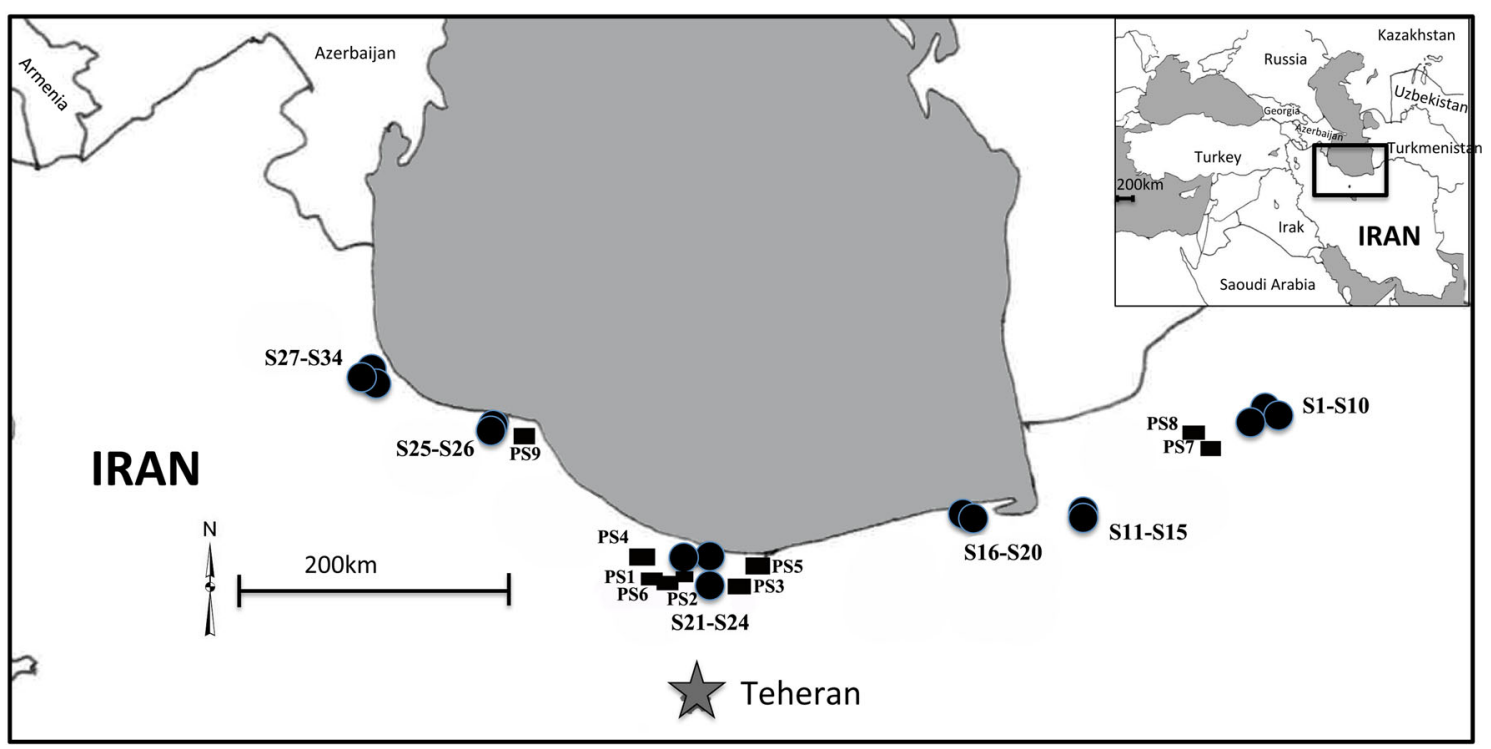

Fig. 1 Distribution of Vitis vinifera subsp. sylvestris populations (S, black filled circle) with reported and unreported pollen sites (PS black filled square) across the Hyrcanian region, N. Iran

Lipsky and Carpinus betulus. Moreover, open woodlands of Quercus macranthera Fisch. and C. A. Mey. ex Hohen., Acer campestre L., Acer hyrcanum Fisch. and C. A. Mey. and Carpinus orientalis Mill. prevail in some upper altitude vegetation.

\section{Data collection and analyses}

To understand the habitat and taxonomic characteristics of wild grapevine, 34 populations were studied across the Hyrcanian area, from the Golestan National Park (eastern Hyrcanian area) to Asalem road (western Hyrcanian area, Guilan) in June 2014 (Appendix S1, see Supplemental Data with online version of this article). Using standard protocols provided by Schnitzer et al. (2008) and Gerwing et al. (2006), the morphological descriptors include: the area covered by grapevine, the ratio of foliage cover to host canopy cover, height in metres and diameter at breast height (DBH). Ecological descriptors include: altitude, openness of habitat (degree of landscape openness: 0 closed forest to 3 open), moisture (degree of moisture across the landscape: 0 dry and semi-dry to 4 wetlands) and distance to the nearest river ( 0 less than $50 \mathrm{~m}$ from the river, 1 more than $50 \mathrm{~m}$ from the river, 2 no river). Among all ampelographic characters of the populations (e.g., Ekhvaia and Akhalkatsi 2010), only some morphological descriptors are correlated with effective environmental features. Despite the high polymorphic status of foliar and flower morphology of wild grapevines (Ekhvaia and Akhalkatsi 2010; Rubio et al. 2012), the amount of foliage cover and stem diameters and heights are considered as morphological responses to habitat requirements. Due to the presence of ordinal and quantitative variables in the dataset, we used Spearman correlation coefficient to study inter-correlation of environmental and morphological variables using SPSS software (version 21).

All materials were examined with a stereomicroscope (NIKON-SMZ1) and compared with samples in the University of Mazandaran Herbarium (HUMZ), the University of Tehran Herbarium (TUH), the herbarium of the Iranian Research Institute of Plant Protection (IRAN), the herbarium of Conservatoire et Jardin botanique de la Ville de Genève $(G)$, the Museum National d'Histoire Naturelle, Paris (P), the Université Montpellier Herbarium (MPU), and the herbarium of Botanical Garden, Munich (M). All special collections of the Geneva herbarium, (including Boissier's Flora Orientalis collections and those collected by P. Aellen, K. H. Rechinger and de Candolle), were also examined. Nomenclature of the plants is according to Flora Iranica (Rechinger 1963-2012) and Flora of Iran (Assadi et al. 1988-2014). Data from herbarium and literature surveys were regrouped in a map showing the distribution points of wild grapevine since the 19th century (Fig. 2). Palynological data of Vitis were obtained from published works (Ramezani et al. 2008, 2016; Leroy et al. 2011; Ramezani 2013; Shumilovskikh et al. 2016) and from unpublished pollen diagrams. Calendar ages (presented as cal. yr BP) were determined using the available age-depth models or by linear interpolation between radiocarbon ages. 
Fig. 2 Records of distribution of wild grapevine populations in Iran since the 19th century based on literature and data from herbarium specimens. Dots represent localities. Mountains are in grey. Seas are in dark

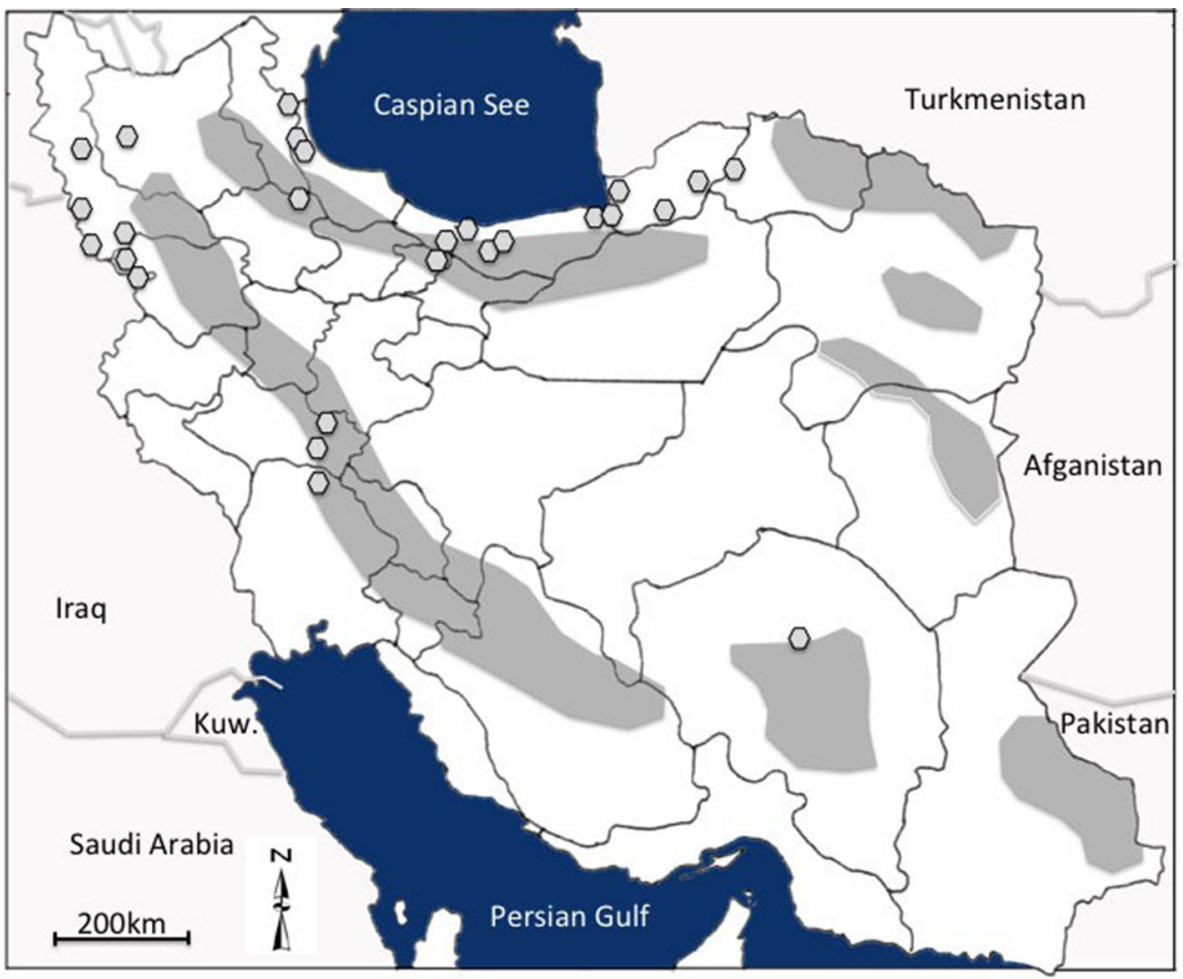

\section{Results and discussion}

\section{Taxonomic remarks and herbarium studies}

Despite being classified as a subspecies under $V$. vinifera, wild grapevine was considered as a separate species, V. sylvestris Gmelin in the Flora Iranica and other local floras (Sosnovskii 1949; Vassilchenko 1970; Sabeti 1976; Mozaffarian 2005). This historical separation into species and subspecies had been based on morphological differences but today this distinction is invalid because differences between wild and cultivated plants are likely the result of domestication over time rather than geographical isolation (This et al. 2006). During domestication, several crucial changes in biology occurred to yield greater sugar content in the berries and more regular production. During this process, both vegetative (berry and branch sizes) and reproductive parts of the plant (seed morphology and the change from dioecious wild plants to hermaphrodite cultivated plants) underwent substantial changes (This et al. 2006).

In Flora of USSR (Sosnovskii 1949), V. hyrcanica Vass. was characterized with tomentose indumentums on the under surface of the leaves. It was, however, later synonymised under $V$. sylvestris (Vassilchenko 1970). Concerning the taxonomical wealth of the genus Vitis in the Flora Iranica realm, two other wild taxa occur, $V$. nuristanica Vassil. and $V$. hissarica Vassil. (the latter subdivided into subsp. hissarica and subsp. rechingeri Vassil.). The latter taxon was recently recorded from a wetland in Khuzestan province, southwest Iran (Dinarvand et al. 2015). The American species $V$. labrusca L. has also been listed as another cultivated species from Guilan and Mazandaran provinces (Mozaffarian 2005).

Besides describing wild grapevine as a separate species in several localities from northern and western parts of Iran in the Flora Iranica, two subspecies ( $V$. sylvestris subsp. anebophylla Kolen. and subsp. trichophylla Kolen.) were proposed within the taxon on the basis of differences in indumentum morphology of the lower surfaces of the leaves (Vassilchenko 1970). In the subsp. anebophylla, the undersides are covered with long arachnoid, appressed hairs (trichomes) which are shed at the end of the growing season, while in subsp. trichophylla, the undersides are covered by small cellular hairs (Vassilchenko 1970). The presence of two different taxa within the $V$. sylvestris group has not been described elsewhere in its distribution area. However, Vitis trichophylla (Kolen.) Vass. was proposed as a separate species in the Flora of USSR among 12 species of $V$. vinifera sensu lato (Sosnovskii 1949).

During several herbarium visits in Paris (P), Geneva (G), Montpellier (MPU) and Munich (M), there were few specimens of $V$. vinifera subsp. sylvestris from Asia and the Caucasus. We found four materials from the Hyrcanian region: (1) $57 \mathrm{~km}$ NE Gonbad-e Ghaboos, $340 \mathrm{~m}$, Pabot7702 (G!); (2) Golestan National Park, Tang-e Gol, 720 m, 
Wendelbo and Foroughi-12853 (G!); (3) 11 km SE Shahpasand (Azadshahr), 220 m, Pabot-7530 (G!); (4) Golestan National Park, Tang-e Gol, 650 m, Kukkonen-7692 (M!). There were five specimens of wild grapevine in these herbaria collected from Kurdistan, Luristan, Zanjan, west Azerbaijan and Kerman.

Vitis sylvestris subsp. trichophylla was determined based on one specimen collected from Mazandaran (Rechinger6662). The exact locality is "Between Kinj and Dasht-e Nazir 800-1300 m" (G!, M!, IRAN!). It is included in the Flora Iranica and corresponds to our sites no. S21-S24 (Fig. 1). This specimen was originally named under $V$. sylvestris subsp. torulosa Vass. and considered as TYPUS specimen in the Geneva and Munich herbaria (Fig. 3). However, although the description of the taxon has never been published, it is mentioned as the only specimen of subsp. trichophylla in the Flora Iranica. Moreover, there is a specimen in the Geneva herbarium under the name of Vitis sylvestris subsp. anebophylla as determined by the author of the Flora Iranica. The specimen was collected in the coastal forests of Bandar-e Gaz, Golestan Province, Rechinger-5524 (cited in Flora Iranica) (Fig. 4). The author also listed five other localities for the subsp. anebophylla which were examined in the herbarium IRAN.

We checked the original descriptions of the two subspecies provided by A. Kolenati in Bull. Soc. Natur. Mosco. (Kolenati 1846) under his classification of wild forms of Vitis vinifera. These were based on morphological variations, particularly those related to indumentums of the leaves. While these two forms of the plant were collected in more or less the same original localities, the authors of Flora Iranica proposed these two forms under the synonymies of $V$. sylvestris, and at the same time as two separate subspecies of $V$. sylvestris. It seems that the separation of subspecies anebophylla and trichophylla was not completely certain for the author of Flora Iranica as he gave localities for Vitis sylvestris at first, and then only based on a few specimens, two subspecies were recognized. This is particularly the case of subsp. trichophylla which is nomenclaturally based on only one specimen. The specimen is not morphologically different from another subspecies except for the indumentum features of the lower surface of the leaves. This finer classification was not followed by other researchers in Iran (Akhani 1998).

According to diagnostic characters in Flora Iranica, all material of 34 populations was carefully checked. They have mostly the features of those described for subsp. anebophylla, i.e., long arachnoid hairs on the lower surface of their leaves. Only specimens from sites S22 and S23 (Mazandaran, Chalus road, Hassanabad, 2 km after deviation toward Kandalous village between Kines and Hassanabad, on the road to Kojour) showed some similarities with the description provided for subsp. trichophylla. However, it was not entirely certain because two forms of the leaves were observed in neighboring populations and also even on the same plant. It would appear that environmental features, especially climate, affect leaf morphological variations of the polymorphic Vitis specimens (Ekhvaia and Akhalkatsi 2010). The occurrence of both forms of the leaves (i.e., both subspecies) in almost the same area is consistent with the localities given in Flora Iranica (Vassilchenko 1970) and observed in the surrounding areas (Ekhvaia and Akhalkatsi 2010).

\section{Morphological peculiarities, habitat characteristics and strategies}

The tallest grapevine $(30 \mathrm{~m}$ ) was found in the closed forests and shrublands of Golestan National Park with Carpinus betulus and Prunus divaricata Ledeb. as dominant species, and the shortest plant $(2 \mathrm{~m})$ was in Miankaleh Biosphere Reserve with Punica granatum L. and Mespilus germanica L. as dominant species. The largest grapevine (DBH: $24.5 \mathrm{~cm}$ ) grew in the shady closed forests of Shastkola Research Forest with Parrotia persica as the dominant species (Fig. 5), while the smallest trunk diameter $(<2 \mathrm{~cm})$ was in the Miankaleh Biosphere Reserve and in Hassanabad populations in open habitats. In valleys at higher
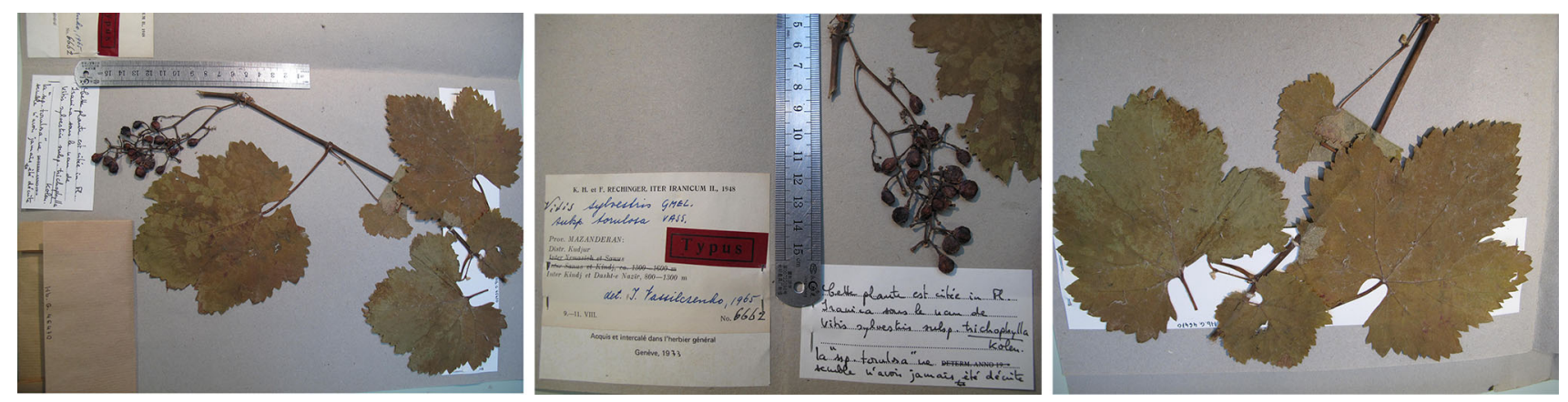

Fig. 3 Vitis sylvestris subsp. trichophylla (sensu Flora Iranica) in the herbarium Geneva (G!) proposed to be a new subspecies (i.e. subsp. torulosa) which was never published and then considered as subsp. trichophylla 

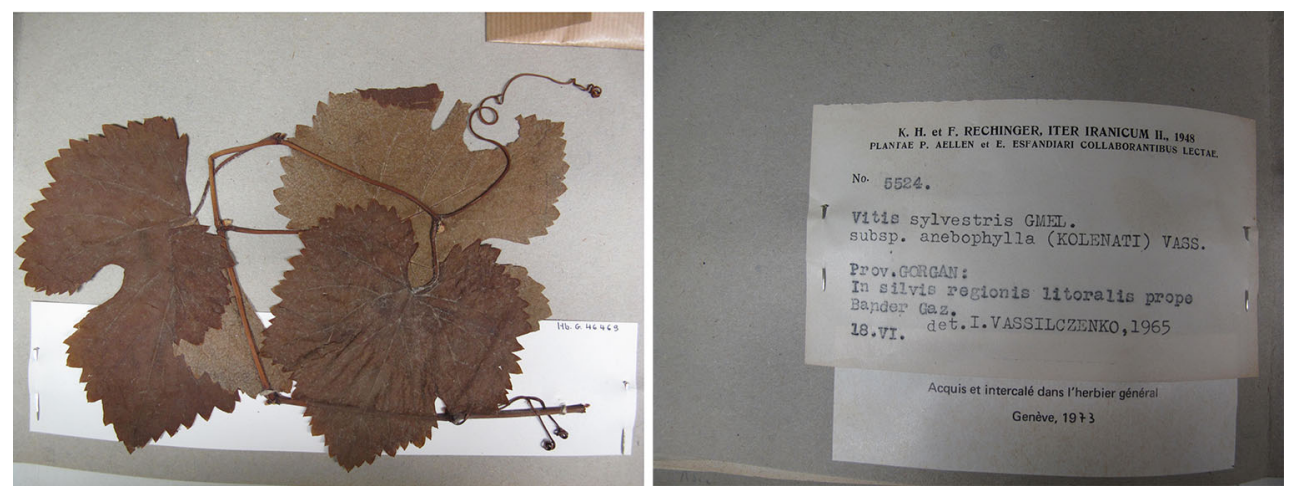

Fig. 4 Vitis sylvestris subsp. anebophylla (sensu Flora Iranica) in the herbarium Geneva (G!)

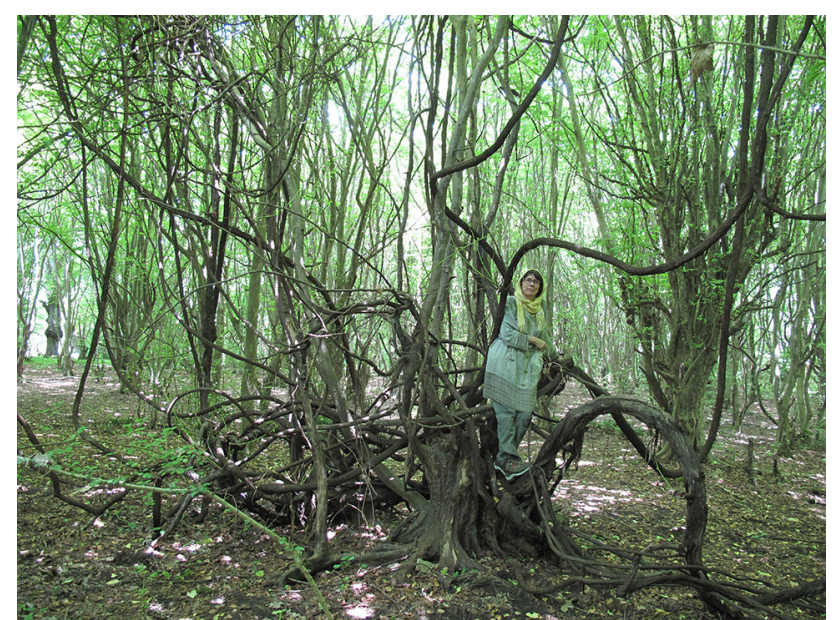

Fig. 5 Giant liana of Vitis vinifera subsp. sylvestris in a dense stand of Parrotia persica in Shastkola Forest, Gorgan

altitudes, plants have thicker leaf densities than those along the sea. This may be due to a more humid environment. DBH, plant height and openness of the landscape were statistically correlated as the grapevines tended to be taller and stronger inside the closed forests. Individuals with larger foliage mostly belonged to plants with higher DBHs but not necessarily to those with taller stems (Table 1). Sites located further from the river are mostly at lower altitudes. It may be interpreted as a sub-tropical lowland environment benefiting from higher rainfalls and temperature (Frey and Probst 1986).

According to our field observations, $V$. vinifera subsp. sylvestris grows in a wide range of habitats, including wetlands, along seasonal rivers and streams, in shady closed forests, on alluvial beds of large rivers, in sand dune shrublands, and forested wetlands (alder forests). In Golestan National Park, north east of Iran, plants grow in different alluvial habitats, in secondary closed shrublands and on river banks along the Khandushan River, alluvial habitats of the Mezalli river bed, and in open shrublands along seasonal rivers near Golzar. It has also been recorded to be a riparian species in Juniperus woodlands of the Park (Akhani 1998).

Except for azonal vegetation of sand dune shrublands and a few wetland and ruderal habitats, all other habitats are classified as lowland and submontane (river basin) forest vegetation below $1000 \mathrm{~m}$ (sensu Frey and Probst 1986; Akhani 1998; Akhani et al. 2010). They are largely represented in two phytosociological alliances ParrotioCarpinion and Alnion subcordatae (e.g., Zohary 1973; Assadollahi 1980; Djazirei 1965; Sabeti 1976; Hamzeh'ee et al. 2008). Moreover, we observed in some of our study sites populations of wild grapevine that had escaped from the closed forest to climb remote trees and shrubs in the forest margin in more favourable habitats. All the sites in this investigation ranged from below zero to 936 m.a.s.l. The highest occurrence of this species was recorded from 2300 m.a.s.l. in Gorgan (Vassilczenko 1970; Sabeti 1976), not observed in the current investigation partly because of the higher destruction situation today in the upper altitudes of the area. Nevertheless, our personal observation over the whole Hyrcanian area indicates that the species is very rare and mainly confined to elevations lower than $500 \mathrm{~m}$. The latter, which is classified as lowland forest, is characterized by sub-tropical, humid closed forest (Zohary 1973; Frey and Probst 1986; Naqinezhad et al. 2008). Based on previous investigations, $V$. vinifera subsp. sylvestris has been reported to be accompanied by other lianas such as Hedera pastuchovii, Smilax excelsa, Jasminum officinale L., Humulus lupulus L. (extremely rare), Periploca graeca L., Dioscorea communis, Calystegia sepium (L.) R. Br. (Sabeti 1976; Browicz 1988). It should be noted that wild grapevine expands its distribution towards west Azerbaijan and Lorestan provinces (Vassilczenko 1970) (Fig. 2).

Wild grapevine grows on a large variety of host species (trees, shrubs or other lianas). Parrotia persica and 
Table 1 Spearman correlation coefficients between the environmental variables across 34 sites of Vitis vinifera subsp. sylvestris populations

\begin{tabular}{|c|c|c|c|c|c|c|c|}
\hline Variables & Moisture & Openness & Distance (m) & $\begin{array}{l}\text { Foliage } \\
\text { cover }\left(\mathrm{m}^{2}\right)\end{array}$ & $\begin{array}{l}\text { Plant } \\
\text { height }(\mathrm{m})\end{array}$ & $\mathrm{DBH}(\mathrm{m})$ & $\begin{array}{l}\text { Ratio of foliage cover of } \\
\text { grapevine to host } \\
\text { canopy cover }(\%)\end{array}$ \\
\hline Altitude & $0.35 *$ & -0.19 & $-0.69 * *$ & $0.40 *$ & 0.28 & 0.02 & -0.05 \\
\hline Moisture & & $-0.9 * *$ & $-0.53 * *$ & 0.23 & $0.62 * *$ & $0.47 * *$ & -0.13 \\
\hline Openness & & & 0.16 & -0.17 & $-0.39 *$ & $-0.40 *$ & $0.37 *$ \\
\hline Distance & & & & $-0.49 * *$ & $-0.44 * *$ & -0.28 & -0.15 \\
\hline Foliage cover & & & & & 0.29 & $0.37 *$ & $0.44 * *$ \\
\hline Plant height & & & & & & $0.49 * *$ & 0.11 \\
\hline $\mathrm{DBH}$ & & & & & & & 0.15 \\
\hline
\end{tabular}

$* P<0.05, * * P<0.01$

Carpinus betulus were, however, the most frequent in the studied populations (Appendix S1). Parrotia persica forests of submontane zones have previously been reported as habitat for this liana (Sabeti 1976).

Wild grapevine has also shown various strategies for establishment. On riversides of Golestan National Park, north east of Iran, we have noted an interesting reproductive strategy. Plants easily germinate on the first alluvial terrace where floods regularly destroy other more competitive plants (Fig. 6). By layering, they colonize the second terrace and climb up to the canopy of both terraces, leading to impressive sizes (up to $20 \mathrm{~m}$ long and $25 \mathrm{~cm}$ DBH). They also form numerous secondary axes and abundant foliage. In the Shastkola alluvial forests, wild grapevines have colonised both forest edges and forest interior at least $100 \mathrm{~m}$ from the river. These individuals have often reached impressive size such as in the Golestan National Park, especially near gaps where possibly old channels occurred and are now recovered with closed forest.

Strategies for growth and survival of the wild grapevine are different in the sand dune shrublands of Miankaleh Biosphere along the coast of the Caspian Sea. The vegetation forms scattered patches of small-diameter bushes of Punica granatum, Rhamnus pallassii Fisch. \& C. A. Mey. and Mespilus germanica. The wild grapevine here has small diameters and germinates at the edges of spiny bushes, spreading leaves on the surface of the bush. Large amounts of fruits are produced in the early summer.

\section{Conservation}

In Iran, wild grapevine has been recognized to be at risk of local extinction in the Zagros Mountains and in northwestern Iran (Doulati-Baneh et al. 2007, 2014). A similar situation exists in the lowland Hyrcanian forests where many sites have been destroyed or drained and replaced with agricultural fields (Akhani 1998; Siadati et al. 2010; Naqinezhad et al. 2012, 2015). The presence of endangered wild grapevine in some sites is an important observation, given the high conservation value of the sites for birds. Some of these sites are part of Iran's nine Biosphere Reserves of the Biosphere Programme. It is a stopover and wintering area for songbirds and birds of prey, and a suitable zone for nesting owing to the presence of shrubs such $P$. granatum. Their morphology provides protection,
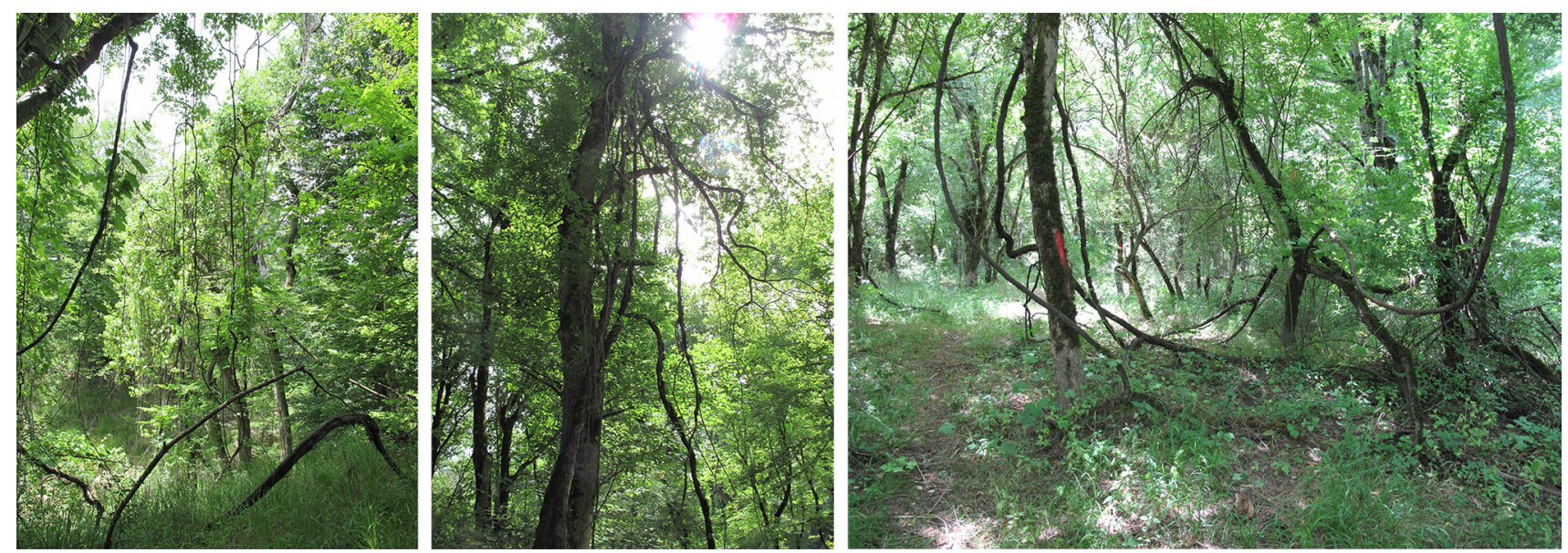

Fig. 6 The habitat of Vitis vinifera subsp. sylvestris in Golestan National Park, north east of Iran 
humidity, and shade during the reproductive season and a source of fruit ( $V$. vinifera subsp. sylvestris, Rubus sanctus Schreb. and Lonicera floribunda) that these birds disseminate after consumption.

No record of occurrence was found of the subspecies in old phytosociological surveys in different places of the Hyrcanian area (e.g. Djazirei 1965; Dorostkar 1974; Assadollahi 1980). Moreover, except for those cited in Flora Iranica, no herbarium records were recorded for this species in the virtual catalogue of International Herbaria. The situation appears similar in the eastern part of its range south of the Caucasus in Georgia (Ramishvili 1988; Ekhvaia and Akhalkatsi 2010; Maghradze et al. 2015).

In the western part of the wild grapevine range in Europe, the main habitats are forest gaps and river edges of flood-prone areas (Arnold 2002). As a woody liana, individuals can live several decades and reach large sizes (i.e., $30 \mathrm{~cm} \mathrm{DBH}$ and lengths of several tens of meters). On alluvial floodplains, wild grapevine populations compete with other woody vines such as Hedera sp., Smilax sp., Clematis vitalba L. and Humulus lupulus (Schnitzler and Arnold 2010). Currently wild grapevine in Europe is present only in remote mountain sites, screes, floodplain forests and islands (Arnold 2002; Arnold et al. 2010; Schneider et al. 2015). The species was added to the IUCN (International Union for Conservation of Nature) list of endangered European plants in the 1980s and was listed as a critically endangered species in 2000 . The plant has been strictly protected in some countries, including France, the Czech Republic, Spain and Italy.

\section{The Holocene history of Vitis in the Hyrcanian region}

Vitis pollen has been frequently reported in Holocene (the last about 11,700 years) pollen records of the South Caspian region. Characteristics of the palynological sites along with the approximate date of the earliest records of Vitis pollen are presented in Table 2.

In pollen identification under a light microscope, the distinction between wild and cultivated species is not possible (Bottema and Woldring 1990). This is the main reason hampering the inference of viticulture in fossil pollen records from the sites located within the natural distribution such as the South Caspian region (Turner and Brown 2004; Miller 2008). However, in southwest Asia, Vitis cultivation can be more certain when additional arboricultural pollen indicators, such as Olea, Castanea, Fraxinus, Cornus, Juglans, and Platanus occur in the pollen records of a given area (Behre 1990; Bottema and Woldring 1990; Djamali et al. 2009; Connor 2011). In some cases, the inadequacy of pollen records may also be compensated with seed morphology analysis in archaeobotanical materials as the latter may help to differentiate material of wild versus cultivated grapevine (Miller 2008). For example, seeds of domesticated grapevines dating back to $8000 \mathrm{BP}$ (6th millennium BC) have been found in Georgia and Turkey (Terral et al. 2010).

On the other hand, considering the entomophilous (insect distributed) mode of pollination in Vitis, along with its low pollen dispersal, it is possible to assess the local presence of this plant even with percentage values as low as $0.1-0.2 \%$ in fossil records (Bottema and Woldring 1990; Turner and Brown 2004). Turner and Brown (2004) have shown that the on-site presence of a vineyard can be strongly evidenced by values as low as $2 \%$.

The Holocene history of wild grapevine in the Hyrcanian region of northern Iran is based on available palynological records. In Iran, the oldest pollen records were found in the catchment area of Lake Urmia in northwest Iran dating back to the last interglacial period (ca. 130 to $115 \times 10^{3}$ years ago) and the following stadial/interstadial intervals from ca 115 to $75 \times 10^{3}$ years ago (Djamali et al. 2008). This finding suggests that the Lake Urmia region is probably located within the natural range of wild grapevine as suggested by Zohary and Hopf (1993). Vitis pollen appear in pollen diagrams from inside the vine distribution area since the beginning of the Holocene (e.g. Lake Ghab, Lake Van, and Lake Urmia), and can be attributed to the wild grapevine (Miller 2008). However, outside its natural range, the vine pollen indicates the spread of viticulture.

In the south Caspian region located within the natural distribution area of Vitis, no pollen record older than the MidHolocene has been established (Table 2). However, low values of Vitis pollen in the oldest pollen records, i.e., Pay Hassal and Kongor (Shumilovskikh et al. 2016), sites suggest either the sporadic incidence of wild grapevines in the immediate surrounding forest communities or the cultivation of its producers (mother plants) somewhere in the Caspian lowlands. Both cases seem quite plausible considering the steep altitudinal gradient from the Caspian lowlands to the Alborz highlands, and the dominant northerly winds which can easily transport pollen grains upslope (Markgraf 1980; Ramezani et al. 2013). This upslope transport is not uncommon as typical Hyrcanian tree pollen in the central Iranian deserts may be found showing that they have crossed the $>3000 \mathrm{~m}$ Alborz Mountains (Moore and Stevenson 1982). The present altitudinal distribution of wild grapevine is mainly confined to lowto mid-elevation (below $1000 \mathrm{~m}$ ) sites (Vassilchenko 1970; Sabeti 1976). In line with this interpretation, the appearance and persistent values of Vitis pollen in the Pay Hassal pollen record since the Mid-Holocene may imply the onset of viticulture in the central Hyrcanian region (Table 2). In the eastern Hyrcanian region, the occurrence of sporadic Vitis pollen in Mid-Holocene may indicate its presence in the wild while its increase since the transition from the late Bronze Age to early Iron Age, in combination with other arboricultural 
Table 2 Site characteristics, the earliest dates of Vitis pollen and the temporal coverage of available palynological records in the Hyrcanian region. Unless otherwise indicated, the most abundant and/or dominant tree species occurring in or around the site are typed bold italic

\begin{tabular}{|c|c|c|c|c|c|c|c|c|}
\hline $\begin{array}{l}\text { Site } \\
\text { no. }\end{array}$ & Site name & $\begin{array}{l}\text { Geographical } \\
\text { coordinates }\end{array}$ & $\begin{array}{l}\text { Altitude } \\
\text { (m. a.s. } \\
\text { 1.) }\end{array}$ & $\begin{array}{l}\text { Temporal } \\
\text { coverage } \\
\text { (cal. yr } \\
\text { BP) }\end{array}$ & $\begin{array}{l}\text { Earliest date } \\
\text { of Vitis pollen } \\
\text { (cal. year BP) }\end{array}$ & $\begin{array}{l}\text { Percentage } \\
\text { values of } \\
\text { Vitis pollen }\end{array}$ & Woody taxa & References \\
\hline 1 & Pay Hassal & $\begin{array}{l}36^{\circ} 31.217^{\prime} \mathrm{N} \\
51^{\circ} 25.017^{\prime} \mathrm{E}\end{array}$ & 1314 & $\begin{array}{l}\text { Entire } \\
\text { Holocene }\end{array}$ & 5000 & $\begin{array}{c}0.8(0.3- \\
1.5)\end{array}$ & $\begin{array}{l}\text { Fagus orientalis, Alnus subcordata, } \\
\text { Carpinus betulus, Acer velutinum, } \\
\text { A. cappadocicum, Cerasus avium, } \\
\text { Ulmus glabra, Sorbus torminalis, } \\
\text { Quercus castaneifolia, Fraxinus } \\
\text { excelsior subsp. coriariifolia, Tilia } \\
\text { platyphyllos, Salix aegyptiaca, } \\
\text { Mespilus germainca, Crataegus sp. }\end{array}$ & $\begin{array}{l}\text { Ramezani et al. } \\
\text { (unpublished } \\
\text { data) }\end{array}$ \\
\hline 2 & Muzidarbon & $\begin{array}{l}36^{\circ} 33^{\prime} \mathrm{N} \\
51^{\circ} 29^{\prime} \mathrm{E}\end{array}$ & 550 & $>1000$ & ca. 950 & $\begin{array}{l}0.3(0.05- \\
1)\end{array}$ & $\begin{array}{l}\text { Carpinus betulus, Parrotia persica, } \\
\text { Acer velutinum, Alnus subcordata, } \\
\text { Pterocarya fraxinifolia, Diospyros } \\
\text { lotus, Quercus castaneifolia, Tilia } \\
\text { platyphyllos, Acer cappadocicum, } \\
\text { Ulmus glabra, Fagus orientalis }\end{array}$ & $\begin{array}{l}\text { Ramezani et al. } \\
\text { (2008) }\end{array}$ \\
\hline 3 & Djamand & $\begin{array}{l}36^{\circ} 30.117^{\prime} \mathrm{N} \\
51^{\circ} 30.417^{\prime} \mathrm{E}\end{array}$ & 1550 & 650 & 550 & $\begin{array}{l}0.3(0.1- \\
0.5)\end{array}$ & $\begin{array}{l}\text { Fagus orientalis, Carpinus betulus, } \\
\text { Alnus subcordata, Acer velutinum, } \\
\text { A. cappadocicum, Cerasus avium, } \\
\text { Fraxinus excelsior subsp. } \\
\text { coriariifolia, Vaccinium } \\
\text { arctostaphyllos, Laurucerasus } \\
\text { officinalis, Ilex spinigera }\end{array}$ & $\begin{array}{l}\text { Ramezani et al. } \\
\text { (unpublished } \\
\text { data) }\end{array}$ \\
\hline 4 & Tepe Kelar & $\begin{array}{l}36^{\circ} 31.202^{\prime} \mathrm{N} \\
51^{\circ} 11.992^{\prime} \mathrm{E}\end{array}$ & 1080 & 900 & ca. 700 & $2(0.6-4.2)$ & $\begin{array}{l}\text { Scattered individuals of Populus alba, } \\
\text { Salix aegyptiaca, Salix alba, } \\
\text { Crataegus spp., Lonicera } \\
\text { floribunda, Prunus divaricata, } \\
\text { Cornus australis, Rhamnus pallasii }\end{array}$ & $\begin{array}{l}\text { Ramezani } \\
\text { (2013) } \\
\text { Khalili et al. } \\
\text { (unpublished } \\
\text { data) }\end{array}$ \\
\hline 5 & Mazgah & $\begin{array}{l}36^{\circ} 36.283^{\prime} \mathrm{N} \\
51^{\circ} 36.35^{\prime} \mathrm{E}\end{array}$ & -22 & $2600-2700$ & $2600-2700$ & $\begin{array}{c}4.6(0.4- \\
11.8)\end{array}$ & $\begin{array}{l}\text { Remnants of Alnus glutinosa and } \\
\text { Pterocarya fraxinifolia, Scattered } \\
\text { occurrences of Acer velutinum, } \\
\text { Gleditsia caspia, Diospyros lotus, } \\
\text { Prunus divaricata, Morus alba, } \\
\text { Punica granatum, Ficus carica, Vitis } \\
\text { vinifera, Lonicera } \text { sp., Hedera } \\
\text { pastuchovii, Smilax excelsa }\end{array}$ & $\begin{array}{l}\text { Ramezani et al. } \\
\text { (2016) }\end{array}$ \\
\hline 6 & $\begin{array}{r}\text { Kannoo } \\
\text { Hassal }\end{array}$ & $\begin{array}{l}36^{\circ} 31.45^{\prime} \mathrm{N} \\
51^{\circ} 22.8^{\prime} \mathrm{E}\end{array}$ & 1330 & 600 & 600 & $\begin{array}{l}0.3(0.2- \\
0.6)\end{array}$ & $\begin{array}{l}\text { Fagus orientalis, Alnus subcordata, } \\
\text { Carpinus betulus, Cerasus avium, } \\
\text { Quercus castaneifolia, Pterocarya } \\
\text { fraxinifolia, Ulmus glabra, Acer } \\
\text { cappadocicum, Tilia platyphyllos, } \\
\text { Salix aegyptiaca, Frangula alnus }\end{array}$ & $\begin{array}{l}\text { Ramezani et al. } \\
\text { (unpublished } \\
\text { data) }\end{array}$ \\
\hline 7 & $\begin{array}{l}\text { Tuska } \\
\text { Tchal }\end{array}$ & $\begin{array}{l}37^{\circ} 11.65^{\prime} \mathrm{N} \\
55^{\circ} 31.633^{\prime} \mathrm{E}\end{array}$ & 1040 & 2050 & 2000 & $\begin{array}{l}0.71(0.4- \\
2.5)\end{array}$ & $\begin{array}{l}\text { Quercus castaneifolia, Carpinus } \\
\text { betulus, Alnus subcordata, Salix } \\
\text { sp., Pterocarya fraxinifolia, Ulmus } \\
\text { glabra, Juglans regia, Fagus } \\
\text { orientalis }\end{array}$ & $\begin{array}{l}\text { De Beaulieu } \\
\text { et al. } \\
\text { (unpublished } \\
\text { data) }\end{array}$ \\
\hline 8 & Kongor & $\begin{array}{l}37^{\circ} 21.35^{\prime} \mathrm{N} \\
55^{\circ} 23.45^{\prime} \mathrm{E}\end{array}$ & 93 & 6100 & 5800 & & $\begin{array}{l}\text { Open landscape with background } \\
\text { pollen: Quercus castaneifolia, } \\
\text { Carpinus betulus, Alnus subcordata }\end{array}$ & $\begin{array}{c}\text { Shumilovskikh } \\
\text { et al. (2016) }\end{array}$ \\
\hline 9 & Amirkola & $\begin{array}{l}37^{\circ} 21.427^{\prime} \mathrm{N} \\
50^{\circ} 11.703^{\prime} \mathrm{E}\end{array}$ & -20 & $\begin{array}{l}\text { Before } \\
171-223\end{array}$ & $\begin{array}{l}\text { At least } \\
\text { slightly } \\
\text { before } 223\end{array}$ & $<\% 1$ & $\begin{array}{l}\text { Alnus glutinosa, Carpinus betulus, } \\
\text { Ulmaceae, Fagus orientalis, } \\
\text { Quercus castaneifolia }\end{array}$ & $\begin{array}{l}\text { Leroy et al. } \\
\text { (2011) }\end{array}$ \\
\hline
\end{tabular}


species (Juglans and Platanus), strongly suggests its cultivated origin in the southeast Caspian lowlands in Gorgan Plain (Shumilovskikh et al. 2016). This increase in Vitis pollen in association with other cultivated species during the Bronze and Iron Ages is not an exclusive feature of the Hyrcanian area but has been documented in other parts of the Irano-Anatolian region (Bottema and Woldring 1990; Djamali et al. 2011a). The presence of Vitis pollen before the Bronze Age, even if sporadic, suggests that this area may be one of the domestication centers for Vitis or an area with co-occurrence of both wild and cultivated species. However, it should be noted that the cultivation and domestication of wild grapevine appears to have occurred between the seventh and the fourth millennia $\mathrm{BC}$, somewhere in a vast geographical area between the Black Sea and northwest Iran (McGovern et al. 1996; This et al. 2006; Myles et al. 2011), and that one of the earliest evidence of wine production was found in Iran at the Hajji Firuz Tepe site in the northern Zagros mountains ca. 7400-7000 cal yr BP (McGovern 2004; Miller 2008). The exact time and place of grapevine domestication in western Asia is, however, not known due to the incompleteness of archaeobotanical and palynological data from the region (Miller 2008). It seems that the first use of grapes from wild species dates back to the $8^{\text {th }}$ millennium $\mathrm{BC}$, the first evidence of wine production in the 6th millennium $\mathrm{BC}$, but the real domestication and planting of grapevine dates back to the Early Bronze Age (Miller 2008). Pollen evidence can more reliably be used as indicating viticulture in areas located outside the natural distribution of Vitis, e.g., the southern Zagros Mountains in Iran (Miller 2008; Djamali et al. 2011a). However, this does not exclude the fact that the South Caspian region may be considered as a domestication center and/or important viticulture area since at least the Bronze Age. The natural presence of the wild species increases the possibility that domesticated grapevines were selected and vegetatively propagated by Bronze Age people in the Caspian region.

\section{Conclusion}

Our study indicates that wild grapevine ( $V$. vinifera subsp. sylvestris) is sporadically distributed in the Hyrcanian region, the eastern edge of its global distribution, and as a result, important for biodiversity conservation. Thirty-four natural populations from below sea level up to 1000 m.a.s.l. were examined. Two variants of anebophylla and trichophylla (within the subspecies sylvestris) in the Flora Iranica were separated only by the indumentums of the leaves and not confirmed by herbarium specimens and material collected in the study sites. Despite to its sporadic nature, $V$. vinifera subsp. sylvestris grows in a wide range of habitats, including wetlands, along seasonal rivers in closed forests, alluvial beds of large rivers, sand dune shrublands and forested wetlands (alder forests). Does the available pollen data reveal further significant spatio-temporal patterns of Vitis populations in the Hyrcanian region over the Mid- to Late-Holocene? Due to the young age of all pollen diagrams from the South Caspian region and the overall sporadic nature of Vitis pollen in most of these records, this cannot be interpreted with certainty. Even the constant and relatively high values throughout the Mazgah pollen record do not reflect changes in the frequencies of its producer in the Caspian lowlands (Table 2). The question of wild versus cultivated grapevine in the Hyrcanian pollen records and the possible date of its domestication and/or cultivation will remain open until further palynological and archaeobotanical studies are undertaken in the area. The natural and/or anthropogenic origins of the Late-Holocene populations of Vitis require older pollen records covering at least the entire Holocene with a higher spatial resolution.

Acknowledgements This research was supported by the Centre for International Scientific Studies and Collaboration (CISSC) and the French Embassy in Tehran under the "Gundishapour" project. We thank Pierre Lhote of the French Embassy for his encouragement during the study, and Nicolas Fumeaux (Geneva), Florian Jabbour (Paris) and Caroline Loupe (Montpellier) for their herbarium assistance. We also thank V. Kheirabadi and M. Madadi and other staff of the Golestan Nationa Park, R. Esmailnejad, Astaneh Ashrafieh, M. Naseri, Asalem, for all their support during field studies. This study was carried out with permission from the Department of Environment for the Golestan National Park and the Miankaleh Biosphere Reserve under permission 93/10330, and by the protection of the Department of Forestry, Gorgan University for the Shastkola forest under permission 93/24/17431.

\section{References}

Akhani H (1998) Plant biodiversity of Golestan National Park, Iran. Stapfia 53:1-411

Akhani H (2005) The illustrated flora of Golestan National Park, Iran. University of Tehran Publication, Tehran, pp 1-481

Akhani H, Djamali M, Ghorbanalizade A, Ramezani E (2010) Plant biodiversity of Hyrcanian relict forests, north Iran: an overview of the flora, vegetation, palaeoecology and conservation. Pak J Bot special issue 42:231-258

Arnold C (2002) Ecologie de la vigne sauvage (Vitis vinifera L. subsp. sylvestris (Gmelin) Hegi.) dans les forêts alluviales et colluviales d'Europe. Geobot Helv 76:1-256

Arnold C, Schnitzler A, Parisot C, Maurin A (2010) Historical reconstruction of a relictual population of wild grapevine (Vitis vinifera subsp. sylvestris) in a floodplain forest of the upper Seine valley, France. River Res Appl 26:904-914

Arrigo N, Arnold C (2007) Naturalised Vitis rootstocks in Europe and consequences to native wild grapevine. PLoS ONE 2:e521

Asri Y, Shrifnia F, Gholami TT (2007) Plant associations in Miankaleh Biosphere reserve, Mazandaran province (N. Iran). Rostaniha 8:1-16 (in Persian)

Assadi M, Maassoumi A, Mozaffarian V (eds) (1988-2014) Flora of Iran, vols. 1-78. Research Institute of Forests and Rangelands Publication, Tehran (in Persian)

Assadollahi F (1980) Etude phytosociologique et biogéographique des forêts hyrcaniennes. Essai synthétique et application à la 
région ďAssalem (Iran). Ph.D. thesis. University of Marseille, Marseille, pp 1-127

Behre KE (1990) Some reflections on anthropogenic indicators and the record of prehistoric occupation phases in pollen diagrams from the Near East. In: Bottema S, Entjes-Nieborg G, van Zeist W (eds) Man's role in the shaping of the Eastern Mediterranean landscape. Balkema Publication, Rotterdam, pp 219-229

Bottema S, Woldring H (1990) Anthropogenic indicators in the pollen record of the eastern Mediterranean. In: Bottema S, EntjesNieborg G, Van Zeist W (eds) Man's role in the shaping of the Mediterranean landscape. Balkema Publication, Rotterdam, pp 231-264

Browicz K (1988) Chorology of trees and shrubs in south-west Asia and adjacent regions, vol 6. Polish Scientific Publishers, Warszawa-Poznán, pp 1-34

Connor SE (2011) A Promethean Legacy: late Quaternary vegetation history of Southern Georgia, the Caucasus. Ancient Near Eastern studies supplement 34. Peeters Publishers, Louvain, pp 1-421

de Andres MT, Benito A, Perez-Rivera G, Ocete R, Lopez MA, Gaforio L, Munoz G, Cabello J, Martinez-Zapater JM, ArroyoGarcia A (2012) Genetic diversity of wild grapevine populations in Spain and their genetic relationships with cultivated grapevine. Mol Ecol 21:800-816

Dinarvand M, Ejtehadi H, Jankju M, Andarzian B (2015) A new record of the genus Vitis (Vitaceae) for the flora of Iran. Iran J Bot 21:100-102

Djamali M, de Beaulieu JL, Shah-Hosseini M, Andrieu-Ponel V, Ponel P, Amini A, Akhani H, Leroy SA, Stevens L, Lahijani H, Brewer S (2008) A late Pleistocene long pollen record from Lake Urmia, NW Iran. Quat Res 69:413-420

Djamali M, De Beaulieu JL, Miller NF, Andrieu-Ponel V, Berberian M, Gandouin E, Lahijani H, Ponel P, Salimian M, Guiter F (2009) A late Holocene pollen record from Lake Almalou in NW Iran: evidence for changing land-use in relation to some historical events during the last 3700 years. J Archaeol Sci 36:1346-1375

Djamali M, Miller NF, Ramezani E, Akhani H, Andrieu-Ponel V, de Beaulieu JL, Berberian M, Guibal F, Lahijani H, Lak R, Ponel P (2011a) Notes on the arboricultural and agricultural practices in ancient Iran based on new pollen evidence. Paléorient 36:175188

Djamali M, Akhani H, Khoshravesh R, Andrieu-Ponel V, Ponel P, Brewer S (2011b) Application of the global bioclimatic classification to Iran: implications for understanding the modern vegetation and biogeography. Ecol Mediterr 37:91-114

Djazirei MH (1965) Contribution à ľ étude des forêts primaires de la Caspienne. Bull Inst Agron Gembloux 33:36-71

Domoers M, Kaviani M, Schaefer D (1998) An analysis of regional and intra-annual precipitation variability over Iran using multivariate statistical methods. Theor Appl Climatol 61:151-159

Dorostkar H (1974) Contribution à l étude des forêts du district Hyrcanien oriental (Chaine de Gorgan). Gembloux, Gembloux, pp 1-202

Doulati-Baneh H, Mohammadi SA, Labra M (2013) Genetic structure and diversity analysis in Vitis vinifera L. cultivars from Iran using SSR markers. Sci Hortic 160:29-36

Doulati-Baneh H, Seyed Abolghasem M, Labra M, De Mattia F, Bruni I, Mezzasalma V, Abdollahi R (2014) Genetic characterization of some wild grapevine populations (Vitis vinifera supsp. sylvestris) of Zagros Mountains (Iran) to identify a conservation strategy. Plant Genet Resour Charact Util 13:27-33

Doulaty-Baneh H, Grassi F, Mohammadi A, Nazemieh A, De Mattia F, Imazio S, Labra M (2007) The use of AFLP and morphological markers to study Iranian grapevine germplasm to avoid genetic erosion. J Hortic Sci Biotech 82:745-752
Ekhvaia J, Akhalkatsi M (2010) Morphological variation and relationships of Georgian populations of Vitis vinifera L. subsp. sylvestris (C.C. Gmel.) Hegi. Flora 205:608-617

Ekhvaia J, Gurushidze M, Blattner FR, Akhalkatsi M (2014) Genetic diversity of Vitis vinifera in Georgia: relationships between local cultivars and wild grapevine, $V$. vinifera subsp. sylvestris. Genet Resour Crop Evol 61:1507-1521

Frey W, Probst W (1986) A synopsis of the vegetation of Iran. In: Kürschner H (ed) Contribution of the vegetation of southwest Asia. Dr. Ludwig Reichert, Wiesbaden, pp 1-43

Gerwing JJ, Schnitzer SA, Burnham RJ, Bongers F, Chave J, DeWalt S, Ewango CEN, Robin Foster R, Kenfack D, Miguel Martı́nezRamos M, Parren MN, Parthasarathy N, Pe'rez-Salicrup DR, Putz FE, Thomas DW (2006) A standard protocol for liana census. Biotropica 38:256-261

Grassi F, De Mattia F, Zecca G, Sala F, Labra M (2008) Historical isolation and Quaternary range expansion of divergent lineages in wild grapevine. Biol J Linn Soc 95:611-619

GRIN (2016) National Germplasm Resources Laboratory, Beltsville, Maryland [Online Database]. Ćhttp://www.ars-grin.gov/cgi-bin/ npgs/html/tax_search.pl. Accessed 08 Oct 2016

Hamzeh'ee B, Naqinezhad A, Attar F, Ghahreman A, Assadi M, Prieditis N (2008) Phytosociological survey of remnant Alnus glutinosa subsp. barbata communities in the lowland Caspian forests of northern Iran. Phytocoenologia 38:17-132

Hegi G (1966) Vitis. In: Band V, Teil I (eds) Illustrierte Flora von Mitteleuropa. Paul Parey Verlag, Hamburg, pp 30-33

Karataş DD, Karataş H, Laucou V, Sarikamiş G, Riahi L, Bacilieri R, This P (2014) Genetic diversity of wild and cultivated grapevine accessions from southeast Turkey. Hereditas 151:73-80

Kolenati FA (1846) Versuch einer systematischen Anordnung der in Grusinien einheimischen Reben nebst einem oekonomischtechnischen Anhange. Bull Soc Sci Nat Moscou 19:283-371

Leroy SG, Arpe K (2007) Glacial refugia for summer-green trees in Europe and south-west Asia as proposed by ECHAM3 time-slice atmospheric model simulations. J Biogeogr 34:2115-2128

Leroy SAG, Roiron P (1996) Final Pliocene macro and micro floras of the palaeovalley of Bernasso (Escandorgue, France). Rev Palaeobot Palyno 94:295-328

Leroy SAG, Lahijani HAK, Djamali M, Naqinezhad A, Moghadam MV, Arpe K, Shah-Hosseini M, Hosseindoust M, Miller CS, Tavakoli V, Habibi P (2011) Late Little Ice Age palaeoenvironmental records from the Anzali and Amirkola Lagoons (south Caspian Sea): vegetation and sea level changes. Palaeogeogr Palaeoecol 302:415-434

Maghradze D, Salimov V, Melyan M, Musayev M, Ocete CA, Chipashvili R, Failla O (2015) Ecological and sanitary characteristics status of the Eurasian wild grapevine in the South Caucasian region. Vitis 54:203-215

Markgraf V (1980) Pollen dispersal in a mountain area. Grana 19:127-146

McGovern PE (2004) Ancient wine: the search for the origins of viniculture. Princeton University Press, Princeton, pp 1-392

McGovern PE, Glusker DL, Exner L (1996) Neolithic resinated wine. Nature 381:480-481

Miller NF (2008) Sweeter than wine? The use of the grapevine in early western Asia. Antiquity 82:937-946

Moore PD, Stevenson AG (1982) Pollen studies in dry environments with particular reference to Turan. In: Spooner B, Mani HS (eds) Desertification and development: dryland ecology in social perspective. Academic Press, London, pp 249-268

Mozaffarian V (2005) Trees and shrubs of Iran. Farhang Moaser Publishers, Tehran, pp 1-1054

Myles S, Boyko AR, Owens CL, Brown PJ, Grassi F, Aradhya MK, Prins B, Reynolds A, Chia JM, Ware D, Bustamante CD (2011) 
Genetic structure and domestication history of the grapevine. Proc Natl Acad Sci 108:3530-3535

Naqinezhad A, Hamzeh'ee B, Attar F (2008) Vegetation-environment relationships in the alderwood communities of Caspian lowlands, N. Iran (toward an ecological classification). Flora 203:567-577

Naqinezhad A, Bahari SH, Gholizadeh H, Esmaei R, Hamzeh'ee B, Djamali M, Moradi H (2012) A phytosociological survey of two lowland Caspian (Hyrcanian) remnant forests, Northern Iran, for validation of some forest syntaxa. Phytol Balc 18:173-186

Naqinezhad A, Zare-Maivan H, Gholizadeh H (2015) A floristic survey of the Hyrcanian forests in Northern Iran, using two lowland-mountain transects. J Forest Res 26:187-199

Ramezani E (2013) Palynological reconstruction of late-Holocene vegetation, climate, and human impact in Kelardasht (Mazandaran Province, N Iran). Iran J For Poplar Res 21:48-62 (in Persian with English abstract)

Ramezani E, Marvie Mohadjer MR, Knapp HD, Ahmadi H, Joosten H (2008) The late-Holocene vegetation history of the Central Caspian (Hyrcanian) forests of northern Iran. Holocene 18:305319

Ramezani A, Haddad R, Dorostkar M, Mardi M, Naghavi MR (2009) Evaluation of genetic diversity of Iranian grapevine accessions using microsatellite markers. Vitis 48:151-152

Ramezani E, Marvie Mohadjer MR, Knapp HD, Theuerkauf M, Manthey M, Joosten H (2013) Pollen-vegetation relationships in the central Caspian (Hyrcanian) forests of northern Iran. Rev Palaeobot Palyno 189:38-49

Ramezani E, Mrotzek A, Marvie Mohadjer MR, Abdollahi Kakroodi A, Kroonenberg SB, Joosten H (2016) Between the mountains and the sea: late Holocene Caspian Sea level fluctuations and vegetation history of the lowland forests of Northern Iran. Quat Int 408:52-64

Ramishvili R (1988) Dikorastushchii vinograd Zakavkazia (Wild grape of the South Caucasus). Ganatleba, Tbilisi, Russia

Rechinger KH (1963-2012) Flora Iranica, vols 1-178. Academische Druck Verlagsanstalt, Graz

Rubio RO, Rubio EO, Pérez CO, Izquierdo MAP, Rustioni L, Failla O, Chipashvili R, Maghradze D (2012) Ecological and sanitary characteristics of the Eurasian wild grapevine (Vitisvinifera L. ssp. sylvestris (Gmelin) Hegi) in Georgia (Caucasian region). Plant Genet Resour 10:155-162

Ruel JJ, Walker MA (2006) Resistance to Pierce's disease in Muscadiniarotundifolia and other native grapevine species. Am J Enol Viticult 57:158-165

Sabeti H (1976) Forests, trees, and shrubs of Iran, vol 13. University of Yazd Press, Yazd, pp 1-886 (in Persian)
Schneider A, Boccacci P, Ruffa P, Torello Marinoni D, Cavallo L, Festari I, Rotti G, Raimondi S (2015) Identification and characterization of Vitis vinifera subsp sylvestris populations in north-western Italy. Vitis 54:223-225

Schnitzer SA, Rutishauser S, Aguilar S (2008) Supplemental protocol for liana censuses. For Ecol Manag 255:1044-1049

Schnitzler A, Arnold C (2010) Contribution des lianes à la biodiversité méditerranéenne. Ecol Mediterr 36:5-24

Shumilovskikh LS, Hopper K, Djamali M, Ponel P, Demory F, Rostek F, Tachikawa K, Bittmann F, Golyeva A, Guibal F, Talon B, Wang LC, Nezamabadi M, Bard E, Lahijani H, Nokandeh J, Omrani Rekavandi H, de Beaulieu JL, Sauer E, Andrieu-Ponel V (2016) Landscape evolution and agro-sylvo-pastoral activities on the Gorgan Plain (NE Iran) in the last 6000 years. Holocene 26:1676-1691

Siadati S, Moradi H, Attar F, Etemad V, Hamzeh'ee B, Naqinezhad A (2010) Botanical diversity of Hyrcanian forests: a case study of a transect in the Kheyrud protected lowland mountain forests in northern Iran. Phytotaxa 7:1-18

Sosnovskii DI (1949) Vitacee. In: Komarov VL (ed) Flora of the USSR, vol 14. Izdatel'stvo Akademii Nank SSSR, Moscow, Leningrad, pp 674-710

Terral JF, Tabard E, Bouby L, Ivorra S, Pastor T, Figueiral I, Picq S, Chevance JB, Jung C, Fabre L, Tardy C (2010) Evolution and history of grapevine (Vitis vinifera) under domestication: new morphometric perspectives to understand seed domestication syndrome and reveal origins of ancient European cultivars. Ann Bot 105:443-455

This P, Lacombe T, Thomas MR (2006) Historical origins and genetic diversity of wine grapevines. Trends Genet 22:511-519

Turner SD, Brown AG (2004) Vitis pollen dispersal in and from organic vineyards: I. Pollen trap and soil pollen data. Rev Palaeobot Palyno 129:117-132

Van Zeist W, Bottema S (1977) Palynological investigations in western Iran. Palaeohist Bussum 19:19-85

Vassilczenko LT (1970) Vitaceae. In: Rechinger KH (ed) Flora Iranica, vol 74. Academische Druck Verlagsanstalt, Graz, pp 1-5

Wan Y, Schwanninger H, Li D, Simon CJ, Wang Y, He P (2008) The ecogeographic distribution of wild grapevine germplasm in China. Vitis 47:77-80

Zecca G, Abbott JR, Sun WB, Spada A, Sala F, Grassi F (2012) The timing and the mode of evolution of wild grapevines (Vitis). Mol Phylogenet Evol 62:736-747

Zohary M. 1973. Geobotanical foundations of the Middle East. 2 vols. Stuttgart: Fischer, p. 1-739

Zohary D, Hopf M (1993) Domestication of plants in the Old World. Clarendon Press, Oxford, pp 1-280 